\title{
SPORTS IDIOMS IN EVERYDAY SOCIAL AND POLITICAL LANGUAGE
}

\author{
Olena Tsvetaeva \\ $\mathrm{PhD}$, Associate Professor, Oles Honchar Dnipro National University, Ukraine \\ e-mail: lenatsv@ukr.net, orcid.org/0000-0002-8072-6578
}

\section{Tetiana Prishchepa}

$\mathrm{PhD}$, Associate Professor, Oles Honchar Dnipro National University, Ukraine e-mail: pettytyrant06@gmail.com,orcid.org/0000-0002-0665-0907

\section{Summary}

The proposed article is devoted to the study of set expressions (idioms) transformed from sports vocabulary to everyday language. The features and variations of idioms translation from English into Ukrainian are analyzed on the material of American social and political press. It should be noted that the skillful use of idioms makes the language brighter, expressive, emotionally colored, and evokes certain associations in the reader. It becomes obvious that the final decision on how to use one way or another translation technique of an idiom depends on the context. The article stresses that the use of idioms makes it possible to solve one of the main objectives of journalistic style combined with the highest level of informativeness expressive emotional fullness material. The correct application of any translation technique or method involves a creative approach to solving each specific problem. It is stressed that sports idioms are an important component of the language of modern life. Such phraseological units provide imagery and expressive expressiveness of modern journalistic discourse.

Keywords: idioms, set expressions, phrase logical unit, sports vocabulary, translation, language of journalism.

\section{DOI: https://doi.org/10.23856/3854}

\section{Introduction}

An idiom is a phraseological unit of language. The problems of phraseology are well studied. The Swiss linguist Charles Bally is considered to be the ancestor of the theory of phraseology for his significant influence on the development of modern phraseology. The development and substantiation of the theoretical foundations of phraseology are connected with the names N. M. Amosova, V. V. Vinogradov, B. O. Larina, M. McCarthy, S. I. Ozhegov, Y. D. Polivanov, and others. The research work in this field was continued by such well-known modern phraseologists as O. M. Babkin, I. K. Bilodid, M. A. Zhovtobryukh, I. G. Cherednichenko, and others.

The subject of phraseology is the phraseological units of a particular language or group of languages. This concept was first used by Charles Bally, a prominent French linguist in his 1909 book "Traité de stylistique française". The first was the Russian literary critic and linguist V. V. Vinogradov in his 1946 book "Basic Concepts of Russian Phraseology as a Linguistic Discipline", among Soviet scholars.

It is believed that despite a large number of studies in the field of phraseology and, the sufficient development of the theoretical basis for distinguishing the units that make up the subject of phraseology, there is still a great variety of definitions and classification criteria. This complicates the consolidation of systematic and scientific research on this topic. 


\section{Some difficulties in the classification of phraseology}

The variety of terminology to describe a particular phraseological phenomenon significantly complicates attempts to classify. External features that define a certain category of phraseological units are related to the form, the established order of the elements, the impossibility of their division, those of their construction, and so on. Internal features are related to the fact that the phraseological unit embodies the act of unitary thinking, the ability to replace a combination of words with one word, equivalent in meaning; forgetting the meaning of the constituent elements of the phrase, the homonymous distance from the corresponding free combinations. The terms used to denote the phraseological unit that received the most attention in the linguistic literature were "phraseologisms" and "idioms." Sometimes even a vague distinction between the two terms and their parallel use with the same meaning is common practice. In the literature on phraseology, various terms such as idiom, phraseology, or word-group are often used to denote the same concept. The term "phraseology" is more common in Ukrainian or Russian scholars, and the "idiom" is very common in the works of European and American linguists.

According to I. K. Bilodid, "a phraseological unit is a lexical-grammatical unity of two or more differently formed components, grammatically organized according to the model of a phrase or organized according to the model of a phrase or sentence, which, having a holistic meaning, is reproduced in the language by tradition, automatically." (Bilodid, 1973: 334).

A. A. Shakhmatov called phraseology "indecomposable compounds that consist of two or more words, form a grammatical whole, but act in such a form that excludes the possibility of recognizing their interdependence and does not allow to recognize any of them as an independent member of the sentence." (Shakhmatov, 1967: 106).

"The Russian-English phrasebook" offers the following definition: "Phraseology is interpreted as a dependent combination of two or more words that interact as a semantic whole. In most cases, the meaning of phraseology can not be predicted in terms of components" (Lubenska, 2004). This phrasebook was compiled by Sofia Lubenska who is a professor of Slavic languages at New York State University in Albany.

W. McMordie gives the following definition of an idiom: "We can say that an idiom is a number of words which, taken together, mean something different from the individual words of the idiom when they stand alone" in his book "Idioms of the English language and their use" (McMordie, 1988).

R. Moon defines an idiom as "an ambiguous term, used in conflicting 'ways. In lay or general use, idiom has two main meanings. First, idiom is a particular means of expressing something in language, music, art, and so on,' which characterizes a person Secondly (and much less commonly in English), an idiom is a particular lexical collocation or phrasal lexeme, peculiar to a language" in his book Stable Expressions and Idioms in English (Moon, 1988: 3).

Mona Baker distinguishes idioms from phrases in terms of transparency of meaning. Quoting Mona Baker, idioms are "frozen patterns of language that allow little or no variation in form and often carry meanings which cannot be deduced from their individual components" in her book "In Other Words" (Baker, 1992: 63).

\section{The use of idioms}

It is necessary to define what it means to "use an idiom". "Use" means the recognition (translation) of idioms in oral and written language, stylistically, semantically and grammatically correct use of them in context. 
For a quality translation of an idiom, it is necessary to have a fundamental mastery of different translation strategies for different types of texts, that is, the translator must be a master of translation. Knowledge of idioms in both the source language and the target language is also essential. Knowing the structure and lexical units of both languages and their features, the translation process can be made correctly and properly.

Peter Newmark, a famous British translation theorist, once noted that "in translating idiomatic into idiomatic language it is particularly difficult to match equivalence of meaning with equivalence of frequency" (Newmark, 1988: 23). He believed that the main problems faced by the translator are not grammatical but lexical, that is, words, phrases, and constant phrases or idioms.

M. Davies mentions a number of problems in the translation of idioms and regular expressions:

- obedience;

- lack of equivalent in the language of translation;

- use of the idiom in the original text both in the literal and in the idiomatic sense at the same time;

- the difference between context and use in the source and target languages (Davies, 2004: 193).

M. Baker believes that "the main problems that idiomatic and fixed expressions pose in translation relate to two main areas: the ability to recognize and interpret an idiom correctly and the difficulties in rendering various aspects of meaning that an idiom or a fixed expression conveys into the target language" (Baker, 1992: 65).

An unacceptable trap for translators is to translate idioms literally. The translation of the idiom "word for word" often makes no sense or even sometimes funny.

James Nolan agrees that "the most common mistake to avoid is not to recognize figurative or idiomatic language and translate it literally" (Newmark, 1988: 67).

Summarizing the above, we believe that the most successful strategy for translating idioms of any language in general and English, in particular, is to select a similar idiom with a similar meaning in the target language.

\section{Examples of idiomatic modification}

Golf has conveyed to everyday speech some really interesting idioms.

UNDER PAR - most people even those who know nothing about sports know that being "under par" in golf is good while being "above par" is bad. In fact, the whole point of golf is to put a small white ball in a tiny pocket for the least number of strokes to be "under-par" as much as possible.

The meaning of this idiom has changed quite suddenly in everyday life. "Under-par" is confusing because it means "worse than usual", while "above par" is something done above face value, exceeding expectations.

For example, in an interview with Business Insider, actor Chris Hemsworth smiled when asked how his children are learning today. "I'm just relaxed in the idea that they're going to come out of this quarantine, you know, IQ a bit under par, a little behind" (Kirsten, 2020).

PAR FOR THE COURSE this phrase for golf refers to the number of strokes required for the required level, but for most people, it will probably mean "something expected."

Yes, we are talking about seasonal floods in the article "Western Springs Main Breaks 'Par For the Course"" in the online edition patch.com (Giuliani, 2020). 
RUN INTERFERENCE means to help by clearing the way through obstacles. In football, he describes the efforts of attacking players to prevent defenders from reaching the player in possession of the ball. For example, "On that play, the Eagles used their biggest receiver, 6-foot-4 Mack Hollins, to run interference on Vikings safety Harrison Smith, who had been assigned man-to-man coverage on Ertz (Krammer, 2018). In everyday use, this idiom can be translated as "solving problems for someone", for example, "Idol plays himself in the film as a first-class passenger on a flight headed to Las Vegas". He gives Sandler's character sage advice on how to win back his love and even helps run interference when Sandler makes his move (Merriam Webster, n.d.).

GAME PLAN is a strategy developed before the game to overcome the opponent. In football, this is traditionally reflected in the form of game diagrams, where players $\mathrm{X}$ and $\mathrm{O}$ represent players. For example, "Putting together a game plan is an elaborate exercise in the art and science of analyzing an opponent's tendencies and patterns and determining how best to exploit them" (Russo, Ralph, 2017).

Any game needs a plan, of course, but with expanded use, "game plan" means "strategy to achieve the goal": "The depth and length of the newspaper advertising collapse has surprised the oldest hands in the industry, so a newcomer like Zell could hardly be expected to have taken it into account for whatever game plan, if any, he had" (Merriam Webster, n.d.).

$\boldsymbol{P U N T}$ in football means to bounce the ball upside down after dropping it from your hands and before it hits the ground. This is done in the hope of giving the ball to the opponent closer to your own goal line because your own chance to move the ball further is unlikely.

Because the player's actions mean giving up trying to score points for their own team, the verb "Punt" began to develop a secondary meaning of "delay or avoid solving a problem". "The U.S. The Supreme Court punted Monday on its biggest decision of its term so far. The justices had been expected to rule on the limits of partisan gerrymandering. Instead, the court sidestepped the major issues on technical grounds, sending the issue back to the lower courts for further examination" (Shakhmatov, 1967).

SIDELINE is a place where injured players sit, as well as a home base for coaches, coaches, inactive players, and anyone who works in a team who is not currently in the game. As a verb, it means to leave someone out of action. This may be the result of illness or injury, but it may also be the result of another decision: "Together, all of these accounts paint a clear picture: Unable to execute his duties for reasons of temperament, ignorance, and mental decline, President Trump has been sidelined by his aides, who work to mitigate his behavior and keep him from steering the country into catastrophe" (Bouie, 2018).

Extremely popular in America, but incomprehensible to many Ukrainians, the game of baseball has enriched the English language with constant expressions that instantly shifted from sports to the vocabulary of everyday use, business, and politics. Here are some examples of baseball idioms, variants of their translation, and examples of transformations into other areas of use.

BALLPARK - “baseball stadium". The term first appeared in the Oxford English Dictionary in 1960 with the additional meaning "estimate", and in 1963 the dictionary added the meaning "scope of activity or influence".

"They said Itanium 'would never be their fastest 32-bit processor, but it' would be in the ballpark Brookwood said” (Shankland, 2003).

"Patrick Wiles a vice president of First Pioneer Farm Credit in Riverhead said the 'ballpark figure' for prime vineyard land on the North Fork is $\$ 50,000$ to $\$ 60,000$ an acre, assuming the development rights have been sold" (Goldberg, 2004). 
BEAN BALL (THROW A BEAN BALL). In baseball, it is an attack by an opponent aimed at his head, a deliberate throw of the ball over his head. In politics, it can be a verbal insult or a policy aimed at significantly offending or harming an opponent. The equivalent of the Ukrainian idiom can be suggested: "throw a stone in the garden."

"Senator Jim Burning Throws Bean ball at America's Unemployed" (Lemer, 2010) Headline.

$\boldsymbol{B R} \boldsymbol{U} \boldsymbol{S H}-\boldsymbol{B} \boldsymbol{A} \boldsymbol{C K}$. In baseball - a nickname for any pitcher (player), designed to establish his team in the inner part of the strike zone; in everyday language, an attempt to undermine influence and power or to threaten verbally.

"The Washington Times' George Archibald reports that Gerald A. Reynolds, assistant secretary for civil rights in the Department of Education, has sent a long overdue brush-back letter to college and university officials concerning their odious and oppressive campus speech codes" (Limbaugh, 2003).

$\boldsymbol{B} \boldsymbol{U S H}-\boldsymbol{L E} \boldsymbol{A} \boldsymbol{G} \boldsymbol{U} \boldsymbol{E}$ - from a baseball term for a second-rate baseball league. The Oxford English Dictionary in 1914 added the meaning "amateur, unsophisticated, unprofessional."

"Kinsley, who does saute off as the stereotypical Los Angeles-hating East Coast wonk, said recently that because L.A. is the second biggest city in the country, it's really bush league to care about 'where the' writers are from"(Seipp, 2005).

CLEANUP-HITTER - An employee hired to solve problems or manage a team. In baseball, it is often the player who is the best reflector in the team and reflects the 4th on the list. The task of the first three is to occupy the bases (download them), and then a "cleanup-hitter" emerges and clears the bases with its blow. The equivalent of this expression can be borrowed from the neologism "crisis manager", a profession that has recently appeared in the Unified Tariff and Qualification Handbook of Work and Workers' Professions.

Referring to President George W. Bush: "There is a reason he is the current president and it is not just because of his Daddy or Money - I think he makes a pretty solid cleanup hitter for the Republican Party and brought home the points made during the previous 4 days of the convention" (Bush Jr.'s Skeleton Closet, 2003).

COVER ONE'S BASES - security. In baseball, the defender covers the base, standing next to it, making it impossible to reach. In business vocabulary, this means "the need to prepare for every accident." If an equivalent translation is required, the phrase "be ready - always ready" can be used.

"Arson investigators sifted through the rubble of an Air- dry Stud barn today but failed to determine the cause of a fire that killed 15 thoroughbred broodmares and yearlings Saturday night. The horses were 'worth more than $\$ 1$ million, according to Brereton Jones, owner of the 3,000 -acre $\left(12 \mathrm{~km}^{2}\right)$ stud farm. 'We don't have any reason to believe it was arson, but you just' want to be sure you cover all the bases, 'he said" (Midway, 1985).

CURVE, CURVEB ALL - a surprise, often completely and completely unexpected, and usually unpleasant. A twisted ball is a throw in a baseball to fool a batter. "Because of that personal story, I'm very interested in illness. One thing we discovered as a family is that when you're thrown a curveball like cancer or multiple sclerosis, often people don't know 'what to do first" (Chu, 2006).

DOUBLE HEADER - "from ship to ball". Two competitions (or similar events) taking place on the same day with the same participants.

“The city's three mayoral candidates finished Wednesday's political double header' with a debate at First Congregational United Church for Christ. ..." (Edwards, 2017). 
EXTRA INNINGS - the extra time allotted to "break the Gordian knot" or solve the problem. In major baseball, that means going beyond standard time in the ninth half of the game. "Microsoft, Yahoo Game Going into Extra innings?" (Morphy, 2008) - Title.

FIRST B ASE - the first step. In baseball, the striker hopes to reach first base and then continue around second and third bases until he reaches "home". In interpersonal relationships, it is a person who cannot get to the first base with another person, unable to achieve the original goal or establish a relationship.

A kiss might be first base in a romantic relationship.

Getting an appointment with a potential customer might be first base in a business transaction or negotiation (an agreement to meet with a potential client may be the first step to a business agreement or negotiation).

FIRST INNING OR EARLY INNINGS - unimportant events or initial stage. Baseball usually lasts 9 innings and usually, the first three innings do not determine the outcome of the game.

"Geithner: Tax reform debate in the first inning" (Baker, 1992) - Title.

"Early Innings of a Banking Recovery" (Frearson, 2011) - Title.

HARDBALL, PLAY HARDBALL - be tough or act aggressively. In sports vocabulary, this concept is derived from a comparison of baseball and softball.

"I think this is just tough bargaining,' said Deborah Ward- well of Dain Bosworth Securities. 'It seems to suggest hardball tactics"' (Freudenheim, 1993).

\section{Conclusions}

Idioms highlight the uniqueness and originality of the language and culture in which they originated, and therefore for their translation, it is necessary to carefully determine the style of the text and, trying to find idiomatic expression in Ukrainian, if possible, translate them according to the original style. Prospects for further research on this issue are an in-depth study of the multifaceted nature of idioms.

\section{References}

Acuna, Kirsten. (1.05.2020). Chris Hemsworth says he is 'failing miserably' at homeschooling his kids and he's at peace with that. Insider. https://www.insider.com/chris-hemsworth-tries-tohomeschool-kids-2020-4

Becker, B. Geithner. (01.27.2011). Tax reform debate in 'first inning. The Hill. http:// thehill.com/policy/finance/140619-geithner-tax-reform-debate-in-firstinning

Baker, M. (1992). In Other Words. London and New York First published http:// www.docdroid.net/9ai3/in-other-words-by-mona-baker.pdf.html

Bilodid, I. K. (1973). Suchasna ukrayinska literaturna mova. [Modern Ukrainian literary language]. Naukova dumka https://www.twirpx.com/file/2421926/ [in Ukrainian]

Bouie, Jamelle. (09.05.2018). The Incapacitated President. Trump's own aides don't trust him to lead the country. Meanwhile, the only people who can stop this crisis pretend it doesn 't exist. Slate. $\quad$ https://slate.com/news-and-politics/2018/09/bob-woodwards-fear-trump-in-the-whitehouse-raises-the-specter-of-the-25th-amendment.html

Bush Jr. 's Skeleton Closet. (2003). Real People For Real Change. Retrieved March 18, 2020, from http://www.realchange.org/bushjr.htm

Chu, J. (27.08.2006). 10 Questions for Meredith Vieira. Msplus. https://msplus.org/default. 
aspx/act/newsletter.aspx/category/NewsWorthy/MenuGroup/Home/NewsLetterID/30/startrow/36.htm? AspxAutoDetectCookieSupport $=1$

Davies, M. G. (2004). Multiple voices in the translation classroom: Activities, tasks and projects. John Benjamins Publishing Company. http://sharonrobertsto.over-blog.com/2018/05/ multiple-voices-in-the-translation-classroom-activities-tasks-and-projects-read-online-ebookdjvu-prc-doc.html

Edwards, A. (28.08.2017). San Bernardino mayoral candidates debate again. Los Angeles Daily News. https://www.dailynews.com/2009/10/21/san-bernardino-mayoral-candidates-debate-again/

Frearson, D. (25.02.2011). Early Innings of a Banking Recovery. Pragcap. http://pragcap.com/ the-early-eamings-of-a-bank-recovery

Freudenheim, M. (14.08.1993). Bristol-Myers Won't Renew Hauser Pact. The New York Times. https://www.nytimes.com/1993/08/14/business/company-news-bristol-myers-won-t-renewhauser-pact.html

Giuliani, David. (28.04.2020). Western Springs Main Breaks 'Par For the Course'. Patch. https://patch.com/illinois/westernsprings/western-springs-main-breaks-par-course

Goldberg, H. G. (18.07.2004). LONG ISLAND VINES; Macari Price: \$9.5 Million. The New York Times. https://www.nytimes.com/2004/07/18/nyregion/long-island-vines-macari-price9.5-million.html

Krammer, Andrew. (01.09.2018). Vikings secondary, linebackers have one option - adjust or fall prey again to run-pass option threat. Star Tribune. https://www.startribune.com/ vikings-secondary-linebackers-have-one-option-adjust-or-fall-prey-again-to-run-pass-optionthreat/492262941/

Lemer, M. (26.02.2010) Senator Jim Bunning Throws Beanball at America's Unemployed. The Faster Times. https://web.archive.org/web/20110716233100/http://thefastertimes.com/ sportschat/2010/02/26/senator-jim-bunning-throws-beanball-at-americas-unemployed/

Limbaugh, D. (18.08.2003). Targeting speech codes on campus. Washington Times. https:// www.washingtontimes.com/news/2003/aug/18/20030818-085538-7222r/

Lubenska S.I. (2004). Bolshoi russko-angliiskii frazeologicheskii slovar. [Comprehensive Russian-English phraseological dictionary]. AST-Press https://books.google.com.ua/books7idM-

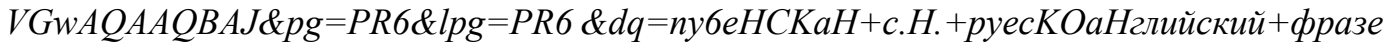
ологический словарь\& воигсеMI\&оIв [in Russian]

McMordie, W. (1988). English Idioms and How to Use Them. Oxford Univ Pr. www.twirpx.com/ file/456044/

Merriam Webster. (n.d.). 7 Idioms from American Football. Tackle these phrases from the gridiron. In Merriam-Webster.com. Retrieved June 01, 2020, from https://www.merriam-webster.com/ words-at-play/7-idioms-from-american-football

Midway, K. (7.01.1985). Sports News Briefs; Fatal Bam Fire Still a Mystery. The New York Times. $\quad$ http://www.nytimes.com/1985/01/07/sports/sports-news-briefs-fatal-barn-fire-still-amystery.html

Moon, R. (1988). Fixed expressions and idioms in English: a corpus-based approach (Oxford Studies in Lexicography and Lexicology). Clarendon Press. https://www.jstor.org/stable $/ 3086652 ? \mathrm{seq}=1$

Morphy, Erika. (6.05.2008). Microsoft, Yahoo Game Going Into Extra Innings? Ecommerce Times. https://www.ecommercetimes.com/story/62892.html

Newmark, P. (1988). A Textbook of Translation. Prentice Hall. https://www.academia.edu/ 25420034/A_TEXTBOOK_OF_TRANSLATION___Peter_Newmark 
Nolan, J. (2005). Professional interpreting in the real world. Multilingual Matters Ltd., http://www.worldcat.org/title/interpretation-techniques-and-exercises/oclc/500943830

Russo, Ralph. D. (17.08.2017). Plan of attack: How a college football coach game-plans. USA Today. https://www.usatoday.com/story/sports/ncaaf/2017/08/17/plan-of-attack-how-a-college-football-coach-game-plans/104676406/

Seipp, C. (24.03.2005). Afflict the Comfortable: Chicks on their Laptops. National Review http://www.nationalreview.com/articles/214000/afflictcomfortable/catherine-seipp

Shankland, S. (23.04.2003). Intel plans Itanium course correction. Cnet https://www.cnet.com/ news/intel-plans-itanium-course-correction/

Shakhmatov, A. A. (1967). Ob osnovnykh tipakh frazeologicheskikh edinits v russkom iazyke. [About main types of phraseological units in Russian]. M. www.twirpx.com/file/1106660049/ [in Russian]

Totenberg, Nina. (18.06.2018). Supreme Court Leaves 'Wild West' Of Partisan Gerrymandering In Place - For Now. NPR. https://www.npr.org/2018/06/18/606017026/supreme-court-puntson-partisan-gerrymandering-leaving-status-quo-in-place 